\title{
Pengaruh Kesadaran Merek, Asosiasi Merek dan Perspesi Kualitas terhadap Kepuasan Konsumen dan Implikasinya terhadap Niat Membeli Ulang Vitamin Merek Holisticare Ester C pada Masa Pandemi Covid 19 di Banda Aceh
}

\author{
Zenitha Maulida ${ }^{1 *}$, Dewi Rosa Indah ${ }^{2)}$ \\ ${ }^{1 *)}$ Program Studi Manajemen, Sekolah Tinggi Ilmu Ekonomi Sabang, Banda Aceh \\ Kp. Pineung, Kota Banda Aceh, Provinsi Aceh, 23115 \\ 2) Program Studi Manajemen, Fakultas Ekonomi, Universitas Samudera \\ Jl. Prof. Dr. Syarief Thayeb, Meurandeh Tengah, Langsa 24415 \\ E-mail: zenitha.abadi@gmail.com ${ }^{1 *}$
}

\begin{abstract}
ABSTRAK
Holisticare Ester $\mathrm{C}$ menghadirkan produk vitamin $\mathrm{C}$ yang berkualitas dalam membantu meningkatkan kesehatan dan imun tubuh. Terciptanya kepuasan konsumen hingga timbulnya niat membeli ulang ini diperoleh karena adanya ekuitas merek yang kuat. Tujuan dari penelitian ini adalah untuk mengetahui pengaruh ekuitas merek yang terdiri dari kesadaran merek, asosiasi merek dan persepsi kualitas terhadap kepuasan konsumen dan implikasinya terhadap niat membeli ulang Vitamin merek Holisticare Ester C pada masa pandemi covid 19 di Kota Banda Aceh. Populasi dalam penelitian ini adalah seluruh konsumen vitamin Holisticare Ester $\mathrm{C}$ dan sampel yang ditarik dalam penelitian ini berjumlah sebanyak 250 responden dengan teknik penarikan sampel secara convinience sampling. Hasil pengujian hipotesis secara simultan diperoleh hasil yang pengaruh yang signifikan, sementara terdapat perbedaan diantara model yang dikemukakan adalah pada pengujian hipotesis secara parsial menunjukkan bahwa variabel kesadaran merek dan asosiasi merek tidak mempunyai pengaruh yang siginifikan terhadap kepuasan konsumen Vitamin Merek Holisticare Ester C pada Masa Pandemi Covid 19 di Kota Banda Aceh.
\end{abstract}

Kata kunci: Kesadaran Merek; Asosiasi Merek; Persepsi Kualitas; Kepuasan Konsumen; Niat Membeli Ulang.

\begin{abstract}
Holisticare Ester $C$ presents quality vitamin $C$ products to help improve health and immunity. This is related to increased consumer satisfaction and repurchase intention. The creation of consumer satisfaction to the emergence of this repurchase intention is obtained because of the strong brand equity. The purpose of this study was to determine the effect of brand equity consisting of brand awareness, brand association and perceived quality on consumer satisfaction and its implications for the repurchase intention of Vitamin Holisticare Ester $C$ during the Covid 19 Pandemic in Banda Aceh. The population in this study were all consumers of vitamin Holisticare Ester $C$ and the sample drawn in this study amounted to 250 respondents with a sampling technique using convinience sampling. The results of simultaneous hypothesis testing have a significant effect, while there is a difference between the models suggested that the partial hypothesis testing shows that brand awareness variables and the brand association variable does not have a significant effect on consumer satisfaction of the vitamin Holisticare Ester C during the Covid 19 Pandemic in Banda Aceh.
\end{abstract}

Keyword: Brand Awareness; Brand Association; Perceived Quality; Consumer Satisfaction;; Purchase Intention. 


\section{PENDAHULUAN}

Pada masa pandemi covid 19 seperti sekarang ini, rutinitas dan kesibukan yang dijalani membuat seseorang harus memberikan perhatian dan waktunya untuk fokus pada kesehatan, karena kesehatan adalah salah satu faktor penting dalam menunjang dan mendukung setiap aktivitas dan rutinitas kerja yang padat, karena didalam tubuh yang sehat terdapat jiwa yang kuat, sehingga kegiatan dan aktivitas kerja akan dapat dikerjakan dengan optimal. Bahkan ada sebuah data statistik dari organisasi kesehatan dunia (WHO) yang mendata bahwa di dunia hanya $15 \%$ orang yang benar-benar sakit dan harus dirawat di rumah sakit, 15\% lagi adalah orang yang benar-benar sehat, dan $60 \%$ selebihnya adalah orang yang sehat tetapi gampang terserang penyakit. Kesehatan tidak hanya terpatok pada kesehatan jasmani saja tetapi sehat secara rohani, sehat pikiran dan akhlak, sehat sosial serta ekonomi dan lain sebagainya. Definisi kesehatan ini termaktub dalam U.U Pokok Kesehatan Nomor 9 tahun 1960, Bab 1 Pasal 2 yang menyebutkan bahwa kesehatan adalah keadaan yang meliputi kesehatan badan (jasmani), rohani (mental), dan sosial serta bukan hanya keadaan bebas dari penyakit, cacat dan kelemahan.

Seiring dengan bertambahnya jumlah yang terinfeksi covid 19 diperlukan berbagai makanan yang bergizi dan suplemen bagi tubuh guna meningkatkan kesehatan dan kebugaran tubuh. Kesehatan dan kebugaran tubuh sangat identik dengan pola makan yang lengkap yaitu yang mengandung seluruh zat gizi yang penting bagi pertumbuhan, kekuatan dan kesehatan dalam proporsi jumlah yang tepat serta aktivitas fisik yang rutin dan teratur. Pada umumnya seseorang memilih untuk mengkonsumsi suplemen atau vitamin karena ingin menikmati tubuh yang sehat dan prima. Tubuh yang sehat dan prima ini diperoleh dari zat-zat gizi seperti karbohidrat, lemak, protein, vitamin dan air.

Di Indonesia saat ini semakin banyak pilihan produk vitamin yang ditawarkan oleh berbagai perusahaan farmasi dengan berbagai macam merek, walaupun kesehatan merupakan yang utama, namun merek dari sebuah produk suplemen atau vitamin menjadi tolak ukur penting bagi konsumen. Dengan kondisi seperti ini akan memposisikan para pemasar untuk selalu merebut dan memperluas pangsa pasarnya. Salah satu aset untuk mencapai keadaan tersebut adalah dengan merek. Menurut Hermawan Kartajaya dalam seminar: Kiat Membangun Brand yang kuat ala Hermawan Kartajaya yang dikutip oleh Jawa Pos menyebutkan bahwa membangun dan menciptakan brand yang kuat, perusahaan harus melakukan sesuatu yang mengena di benak konsumen, tidak sekedar menjual tetapi memiliki implikasi jangka panjang. Merek atau brand bukan hanya sekedar nama bukan pula hanya sekedar logo atau simbol, brand adalah value indicator dari apa yang ditawarkan. Brand 
adalah ekuitas perusahaan yang menambahkan nilai pada produk dan pelayanan yang ditawarkan, sebagai sebuah aset brand menciptakan nilai bagi para konsumen melalui kualitas produk dan kepuasan konsumen. Dengan kata lain brand memiliki keterikatan secara emosional antara konsumen dengan pemasar, bahkan seberapapun pesaing mampu menciptakan produk yang serupa, tetapi mereka tidak bisa menciptakan ikatan emosional yang kuat dengan konsumen. Pemasaran dewasa ini merupakan persepsi konsumen. Membangun persepsi konsumen dapat dilakukan melalui strategi merek. Predikat prestisius pada merek dapat disebut jika memiliki ekuitas merek yang kuat. Suatu produk apabila memiliki ekuitas merek yang kuat, maka dapat membentuk landasan merek yang kuat dan mampu mengembangkan keberadaan suatu merek dalam persaingan apapun dalam jangka waktu yang lama. Kekuatan persaingan itu sendiri adalah persaingan yang terjadi antar merek, maka diperlukan juga ekuitas merek yang kuat. Konsep ekuitas merek akan dapat terjadi jika seorang konsumen memiliki tingkatan yang tinggi terhadap kesadaran terhadap suatu merek dan berpegang pada kekuatan kegemaran, keinginan dan keunikan asosiasi-asosiasi merek dalam ingatannya.

Salah satu penyedia produk Vitamin C yang kini menjadi produk wajib yang dikonsumsi adalah Holisticare Ester C. Banyak merek-merek vitamin C lain yang menjadi pesaing, namun Holisticare Ester $\mathrm{C}$ mempunyai keunggulan produk berupa vitamin $\mathrm{C}$ yang tidak perih dilambung dengan harga yang terjangkau. Saat ini Holisticare telah tumbuh menjadi merek Ester $\mathrm{C}$ paling terkemuka di Indonesia dan telah dipasarkan ke berbagai negara Asia terutama Asia Tenggara. Holisticare Ester C di distribusi oleh PT Indocare yang beroperasi sejak tahun 1988, dan di Tahuun 1991 menjadi pioner Ester C - Vitamin C yang memperkenalkan produknya pada konsumen Indonesia. Kota Banda Aceh sebagai Ibukota Provinsi Aceh adalah pasar yang sangat potensial bagi produk Holisticare Ester C, dikarenakan pusat bisnis ada di Banda Aceh, dan merek ini telah mengantongi sertifikat Halal dari MUI yang notabene menambah kepercayaan masyarakat Banda Aceh yang mayoritas muslim. Selain itu jumlah pasien yang terinfeksi covid 19 di Banda Aceh merupakan yang terbanyak diantara kota dan kabupaten lain di Provinsi Aceh. Bahkan saat ini Banda Aceh adalah Zona Merah Covid 19. Fenomena meningkatnya jumlah pasien yang terinfeksi Covid 19, membuat produk vitamin merek Holisticare Ester $\mathrm{C}$ ini banyak diminati oleh konsumen untuk menjaga imunitas tubuhnya. Bagi konsumen, merek salah satu indikator untuk memutuskan membeli sebuah produk atau tidak, walaupun hal ini berkaitan dengan kesehatan yang banyak menawarkan produk generik.

Dalam menjawab pertanyaan mengenai mengapa seseorang memilih dan membeli 
produk dengan merek tertentu, hal ini berhubungan dengan motivasi dan seorang konsumen. Menurut Schiffman dan Kanuk (2011) motivation is the driving force within individuals that impels them to action, artinya motivasi adalah kekuatan dorongan dari dalam diri individu yang memaksa mereka untuk melakukan tindakan. Implikasinya dalam pemasaran adalah kemungkinan seseorang berminat untuk membeli produk dengan merek tertentu sehingga tercipta kepuasan dan kemudian akan timbul niat membeli ulang (repurchase intention).

Setiap konsumen ingin mendapatkan kepuasan tertinggi dari penggunaan produk. Begitu pula dengan Holisticare Ester $\mathrm{C}$ ketika konsumen mengkonsumsi vitamin ini diharapkan mereka akan merasakan kepuasan tertinggi yang pada akhirnya akan selalu berniat untuk melakukan pembelian kembali dan menjadi pelanggan yang setia (loyal) sekalipun konsumen sudah memiliki pengalaman menggunakan vitamin selain Holisticare Ester C. Tetapi dalam perjalanannya ada juga sebagian konsumen yang tidak merasa puas sehingga mereka berpindah (switch) yang ditandai dengan adanya kecenderungan untuk meninggalkan Holisticare Ester C dan beralih ke produk vitamin lainnya. Adanya perilaku yang berbeda dikalangan konsumen yang berkaitan dengan niat membeli ulang menjadikan konsep tentang kepuasan sangat penting bagi perusahaan karena apabila perusahaan telah mampu menciptakan kepuasan konsumen maka perusahaan tersebut cenderung mampu bertahan disetiap keadaan ekonomi yang terjadi. Kepuasan itu sendiri bergantung pada perkiraan kinerja produk dalam memberikan nilai, relatif terhadap harapan pembeli (Maulida \& Nurbismi, 2017). Kepuasan tinggi atau kesenangan menciptakan kelekatan emosional terhadap merek, bukan hanya preferensi rasional, karena ketika pelanggan puas, maka pelanggan berniat untuk melakukan pembelian ulang dan bahkan merekomendasikan kepada pihak lain. Adanya niat untuk membeli ulang karena adanya ekuitas merek yang kuat dari suatu produk.

Mengacu pada konsep yang dikemukakan oleh Aaker dalam beberapa jurnal bahwa dengan kuatnya ekuitas merek maka konsumen akan merasa puas dan semakin kuat pula daya tarik produk tersebut. Ekuitas merek yang kuat juga akan mempengaruhi niat membeli ulang suatu produk. Ekuitas merek (brand equity) dalam konsep yang dikemukakan oleh Aaker dalam Irzandy, dkk (2017) terdiri dari empat dimensi, yaitu kesadaran merek (brand awareness), asosiasi merek (brand association), persepsi kualitas (perceived quality) dan loyalitas merek (brand loyalty). Dalam penelitian ini, dimensi loyalitas merek tidak dimasukkan karena menurut pendapat Aaker bahwa loyalitas merek dapat berfungsi sebagai salah satu dimensi yang ikut mempengaruhi ekuitas merek. Loyalitas merek berbeda dengan dimensi ekuitas merek lainnya loyalitas merek adalah dimensi yang mempengaruhi dan 
dipengaruhi oleh ekuitas merek. Sehingga permasalahan dalam penelitian ini adalah apakah kesadaran merek, asosiasi merek dan persepsi kualitas berpegaruh terhadap kepuasan konsumen dan bagaimana dampaknya terhadap niat membeli ulang vitamin merek Holisticare Ester C pada Masa Pandemi Covid 19 di Kota Banda Aceh.

\section{METODE PENELITIAN}

Penelitian ini dilakukan di kota Banda Aceh. Objek penelitian adalah tentang kesadaran merek, asosiasi merek dan persepsi kualitas terhadap kepuasan konsumen dan implikasinya terhadap niat membeli ulang vitamin merek Holisticare Ester C Pada Masa Pandemi Covid 19 di Kota Banda Aceh. Populasi penelitian ini adalah seluruh konsumen Holisticare Ester C, sedangkan sampel dalam penelitian ini adalah sebanyak 250 orang responden, berdasarkan pendapat Birn dalam Maulida \& Nurbismi (2017) menyatakan bahwa dalam penelitian kuantitatif tidak memerlukan penggunaan sampel yang terlalu besar. Kebanyakan dari reseach marketing diperbolehkan menggunakan sampel sebesar 200, 250, 500, 800, 1000, atau 2000 responden. Conveneince Sampling adalah teknik pengambilan sampel dalam penelitian ini. Convenience Sampling adalah sebuah teknik non probabilitas yang berupaya memperoleh sampel dengan elemen yang mudah. Teknik pengumpulan data dalam penelitian ini dilakukan melalui penyebaran kuisioner yang dibagikan kepada konsumen Holisticare Ester C. Dalam penelitian ini, untuk melihat pengaruh langsung dan tidak langsung antar variabel, digunakan suatu metode kuantitatif yaitu Analisis Jalur (Path Analysis). Path Analysis merupakan perluasan dari analisis regresi linier berganda dan yang memungkinkan menganalisis model-model yang lebih kompleks. Path Analysis adalah teknik yang dikembangkan oleh Sewal Wrigt di tahun 1934 sebenarnya merupakan pengembangan korelasi yang diurai menjadi beberapa intepretasi akibat yang ditimbulkannya (Hakam, Malik dkk, 2015).

Berdasarkan hipotesis konseptual yang diajukan, diagram jalur terdiri atas tiga persamaan struktural, yaitu:

$\mathrm{Y}=\mathrm{PYX}_{1}+\mathrm{PYX}_{2}+\mathrm{PYX}_{3}+\mathrm{e}$ 


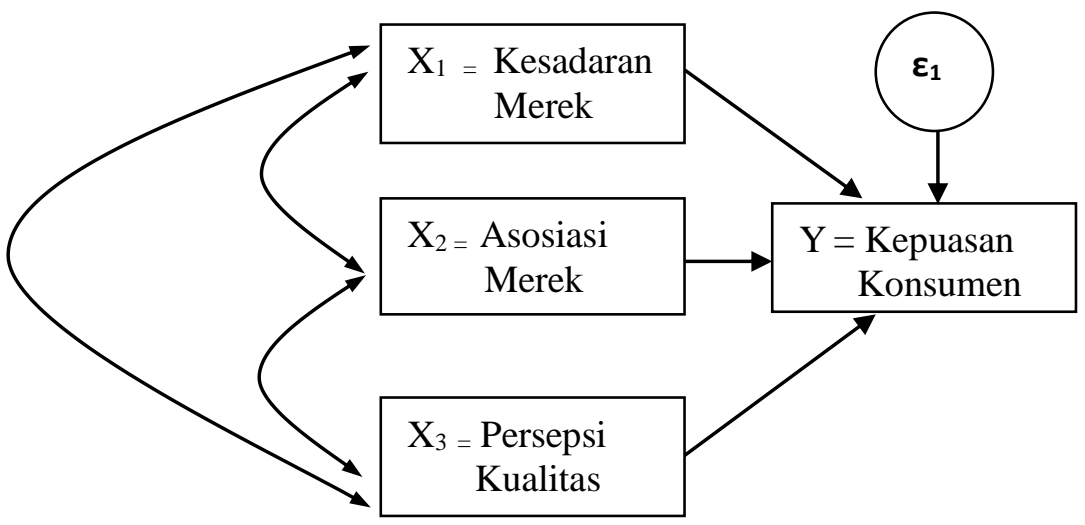

Gambar 1. Analisis Jalur 1

$\mathrm{Z}=\mathrm{PX}_{1} \mathrm{Z}+\mathrm{PX}_{2} \mathrm{Z}+\mathrm{PX}_{3} \mathrm{Z}+\mathrm{e}$

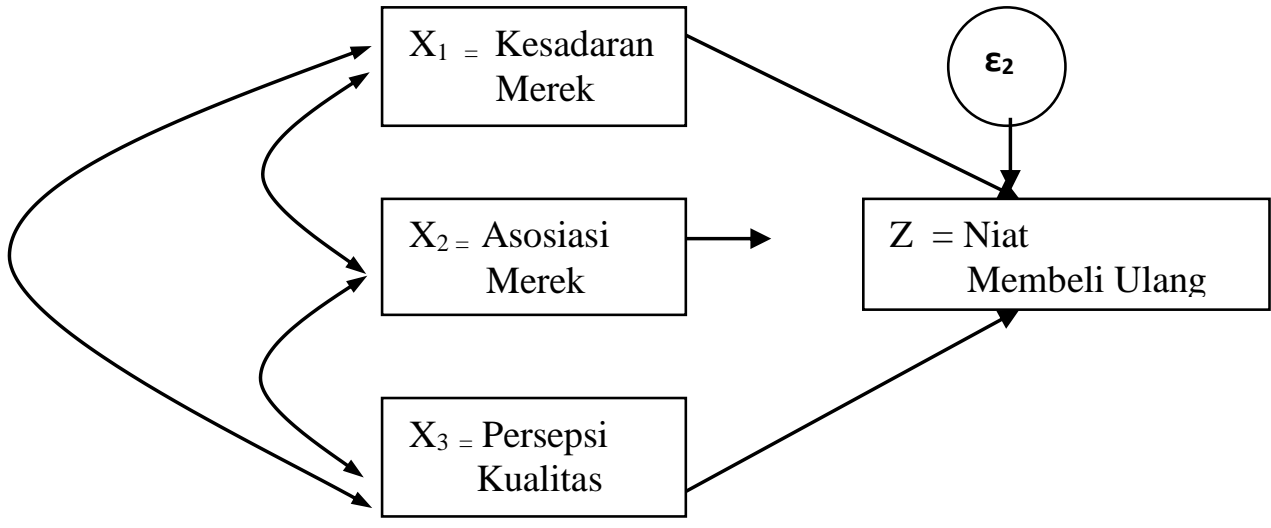

Gambar 2. Analisis Jalur 2

$\mathrm{Z}=\mathrm{PYZ}+\mathrm{e}$

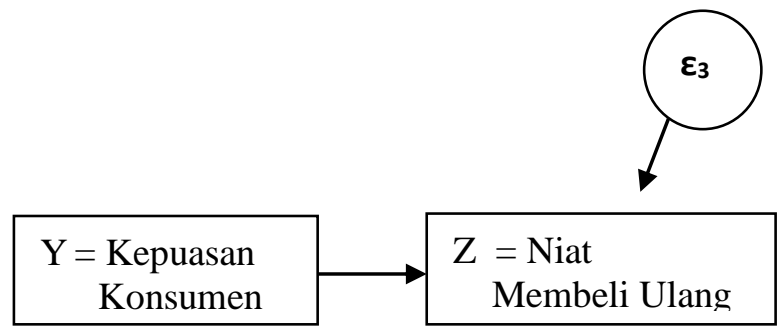

Gambar 3. Analisis Jalur 3

Dimana:

$\mathrm{Y}=$ Kepuasan Konsumen

$\mathrm{Z}=$ Niat Membeli Ulang

$\mathrm{X}_{1}=$ Kesadaran Merek

$\mathrm{X}_{2}=$ Asosiasi Merek 
$\mathrm{X}_{3}=$ Persepsi Kualitas

$\mathrm{e}=$ Error

\section{HASIL DAN PEMBAHASAN}

Pengujian hipotesis pertama dengan menggunakan analisis jalur dilakukan untuk mengetahui besar pengaruh variabel Kesadaran Merek $\left(\mathrm{X}_{1}\right)$, Asosiasi Merek $\left(\mathrm{X}_{2}\right)$, Persepsi Kualitas $\left(\mathrm{X}_{3}\right)$ terhadap Kepuasan Konsumen Vitamin Merek Holisticare Ester C pada masa pandemi Covid 19 di Kota Banda Aceh (Y). Pada metode analisis jalur, untuk mengetahui pengaruh variabel-variabel penelitian atau mencari hubungan kausal antar variabel, maka terlebih dahulu dihitung matriks korelasi dari variabel Kesadaran Merek $\left(\mathrm{X}_{1}\right)$, Asosiasi Merek $\left(\mathrm{X}_{2}\right)$, Persepsi Kualitas $\left(\mathrm{X}_{3}\right)$ dan Kepuasan Konsumen Vitamin Merek Holisticare Ester C pada Masa Pandemi Covid 19 di Kota Banda Aceh (Y).

Korelasi menunjukkan adanya indikasi awal bahwa terdapat hubungan antar variabel. Dari tabel diatas terlihat bahwa korelasi bivariat seluruh variabel adalah signifikan (probability di atas 0,05) berhubungan dengan Kepuasan Konsumen Vitamin Merek Holisticare Ester C pada Masa Pandemi Covid 19 di Kota Banda Aceh. Dari hasil perhitungan pada tabel korelasi tersebut, terlihat bahwa variabel yang memiliki hubungan paling erat dengan variabel Kepuasan Konsumen adalah variabel Persepsi Kualitas $\left(\mathrm{X}_{3}\right)$, yaitu sebesar 0,778. Sedangkan variabel yang memiliki keterkaitan paling kecil dengan variabel Kepuasan Konsumen adalah variabel Kesadaran Merek $\left(\mathrm{X}_{1}\right)$, yaitu sebesar 0,677. Dalam hal ini, nilai korelasi antara Kepuasan Konsumen dengan variabel Persepsi Kualitas $\left(\mathrm{X}_{3}\right)$ lebih besar dibandingkan dengan variabel bebas lainnya. Hal ini mengindikasikan bahwa Persepsi Kualitas $\left(\mathrm{X}_{3}\right)$ lebih berpengaruh terhadap Kepuasan Konsumen dibandingkan dengan variabel lainnya (Kesadaran Merek dan Asosiasi Merek). Hasil perhitungan koefisien jalur (Path Analysis) diperoleh hasil sebagai berikut:

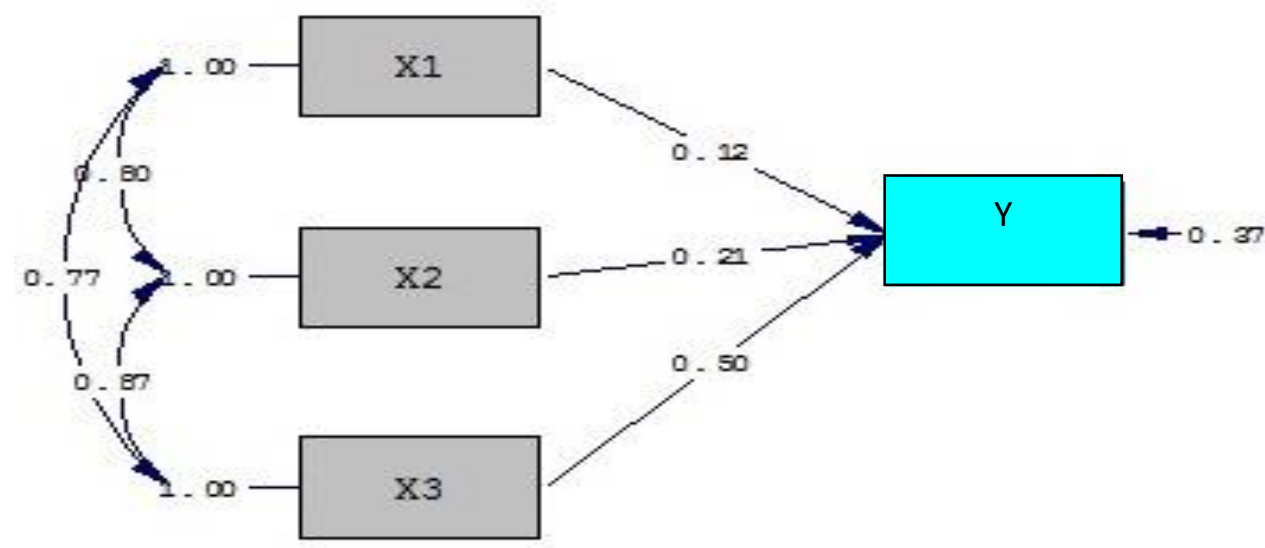

Gambar 4. Hasil Pengujian Jalur 1 
Dari gambar analisis jalur diatas, maka dapat diformulasikan nilai koefisien jalur melalui tabel sebagai berikut :

Tabel 1. Hasil Perhitungan Jalur

\begin{tabular}{|c|c|}
\hline Variabel & Koefisien Jalur \\
\hline Kesadaran Merek $\left(\mathrm{X}_{1}\right)$ & $\rho_{y 1 x 1}=0,123$ \\
\hline Asosiasi Merek $\left(\mathrm{X}_{2}\right.$ & $\rho_{y 1 x 2}=0,213$ \\
\hline Persepsi Kualitas $\left(\mathrm{X}_{3}\right)$ & $\rho_{y 1 \times 3}=0,498$ \\
\hline
\end{tabular}

Sumber : Data diolah, 2020

Tabel di atas menunjukkan gambaran persamaan jalur sebagai berikut:

$\mathrm{Y}=0,123 \mathrm{X}_{1}+0,213 \mathrm{X}_{2}+0,498 \mathrm{X}_{3}$

Dimana:

$\mathrm{X}_{1}=$ Kesadaran Merek

$\mathrm{X}_{2}=$ Asosiasi Merek

$\mathrm{X}_{3}=$ Persepsi Kualitas

$\mathrm{Y}=$ Kepuasan Konsumen

Dari persamaan di atas dapat diartikan bahwa setiap peningkatan Kesadaran Merek sebesar satu satuan, maka akan meningkatkan Kepuasan Konsumen sebesar 0,123 satuan. Setiap peningkatan Asosiasi Merek sebesar satu satuan, maka akan menaikan Kepuasan Konsumen sebesar 0,213 satuan. Setiap peningkatan Persepsi Kualitas sebesar satu satuan, maka akan menaikan Kepuasan Konsumen sebesar 0,498 satuan. Nilai koefisien jalur variabel Persepsi Kualitas lebih besar dibandingkan koefisien jalur untuk variabel bebas lainnya, artinya Persepsi Kualitas mempunyai pengaruh lebih besar terhadap Kepuasan Konsumen dibandingkan variabel bebas lainnya, baik secara langsung maupun tidak langsung.

Untuk menguji signifikansi pada hipotesis pertama, dilakukan pengujian hipotesis secara simultan. Hipotesis pertama penelitian ini adalah Kesadaran Merek, Asosiasi Merek, dan Persepsi Kualitas secara simultan berpengaruh signifikan terhadap Kepuasan Konsumen Vitamin Merek Holisticare Ester C pada Masa Pandemi Covid 19 di Kota Banda Aceh. Berikut hasil pengujian simultan untuk hipotesis pertama: 
Tabel 2. Pengujian Secara Simultan

\begin{tabular}{|c|c|c|c|c|}
\hline Hipotesis Alternatif & F hitung & Db & F tabel & Kesimpulan \\
\hline $\begin{array}{c}\left(\mathrm{X}_{1}, \mathrm{X}_{2}, \mathrm{X}_{3}\right) \text { secara simultan } \\
\text { (bersama-sama) } \\
\text { berpengaruh terhadap } \\
\text { variabel } \mathrm{Y}\end{array}$ & 139,502 & $\begin{array}{l}\mathrm{db}_{1}=3 \\
\mathrm{db}_{2}=246\end{array}$ & 2,64 & $\begin{array}{c}\text { Ho ditolak } \\
\text { (Signifikan) }\end{array}$ \\
\hline
\end{tabular}

Pada tabel di atas dapat kita ketahui bahwa hasil pengujian signifikan yang berarti Kesadaran Merek, Asosiasi Merek, dan Persepsi Kualitas secara simultan memiliki pengaruh signifikan terhadap Kepuasan Konsumen Vitamin Merek Holisticare Ester C pada Masa Pandemi Covid 19 di Kota Banda Aceh. Berdasarkan hasil pengujian secara keseluruhan memberikan hasil yang signifikan, maka untuk mengetahui variabel bebas mana yang secara parsial berpengaruh nyata terhadap Kepuasan Konsumen dapat dilanjutkan dengan pengujian secara parsial yang ditunjukkan dalam tabel dibawah ini:

Tabel 3. Pengujian Secara Parsial

\begin{tabular}{ccccccc}
\hline No & Hipotesis & $\begin{array}{c}\text { Koefisien } \\
\text { Jalur }\end{array}$ & t hitung & db & t tabel & Kesimpulan \\
\hline 1 & $\mathrm{P}_{Y \times 1} \neq 0$ & 0.123 & 1,837 & 248 & 1,96 & Ho diterima \\
2 & $\mathrm{P}_{Y \times 2} \neq 0$ & 0.213 & 2,467 & & 1,96 & Ho ditolak \\
3 & $\mathrm{P}_{Y \times 3} \neq 0$ & 0.498 & 6,209 & & 1,96 & Ho ditolak \\
\hline
\end{tabular}

Sumber: Data diolah, 2020

Dari tabel di atas dapat kita ketahui bahwa semua nilai t hitung untuk ketiga variabel bebas lebih besar dari nilai t tabel, ini berarti Asosiasi Merek, dan Persepsi Kualitas secara parsial memberikan pengaruh yang signifikan terhadap Kepuasan Konsumen Vitamin Merek Holisticare Ester C pada Masa Pandemi Covid 19 di Kota Banda Aceh.

Sedangkan Kesadaran Merek tidak memberikan pengaruh yang signifikan terhadap Kepuasan Konsumen Vitamin Merek Holisticare Ester C pada Masa Pandemi Covid 19 di Kota Banda Aceh karena t hitung lebih kecil dari t tabel. Selanjutnya dihitung pengaruh langsung dan tidak langsung untuk hipotesis pertama yang ditampilkan dalam tabel sebagai berikut: 
Tabel 4. Pengaruh Langsung dan Tidak Langsung Kesadaran Merek terhadap Kepuasan Konsumen

\begin{tabular}{|c|c|c|}
\hline \multicolumn{2}{|c|}{ Pengaruh langsung dan tidak langsung } & Besar Kontribusi \\
\hline X1 langsung & $\mathrm{P}_{Y \mathrm{x} 1} \mathrm{P}_{\mathrm{Yx} 1}$ & 0,0152 \\
\hline X1 melalui X2 & $\mathrm{P}_{\mathrm{Yx} 1} \mathrm{r}_{\mathrm{X} 1 \mathrm{x} 2}$ & 0,0212 \\
\hline X1 melalui X3 & $\mathrm{P}_{\mathrm{Yx} 1} \mathrm{r}_{\mathrm{x} 1 \mathrm{x} 3}$ & 0,0471 \\
\hline Total pengaruh & & 0,0835 \\
\hline
\end{tabular}

Sumber: Data diolah, 2020

Berdasarkan tabel di atas dapat diketahui bahwa total pengaruh yang diberikan variabel Kesadaran Merek $\left(\mathrm{X}_{1}\right)$ terhadap variabel Kepuasan Konsumen Vitamin Merek Holisticare Ester C Pada Masa Pandemi Covid 19 di Kota Banda Acehadalah sebesar 8,35\%.

Tabel 5. Pengaruh Langsung dan Tidak Langsung Asosiasi Merek terhadap Kepuasan Konsumen

\begin{tabular}{lcc}
\hline \multicolumn{2}{c}{ Pengaruh langsung dan tidak langsung } & Besar kontribusi \\
\hline $\mathrm{X} 2$ langsung & $\mathrm{P}_{\mathrm{Yx} 2} \mathrm{P}_{\mathrm{Yx} 2}$ & 0,0455 \\
$\mathrm{X} 2$ melalui X1 & $\mathrm{P}_{\mathrm{Yx} 2} \mathrm{r}_{\mathrm{X} 1 \times 2} \mathrm{P}_{\mathrm{Yx} 1}$ & 0,0212 \\
$\mathrm{X} 2$ melalui X3 & $\mathrm{P}_{\mathrm{Yx} 2} \mathrm{r}_{\mathrm{X} 2 \times 3} \mathrm{P}_{\mathrm{Yx} 3}$ & 0,0922 \\
\multicolumn{2}{c}{ Total pengaruh Variabel X2 terhadap Variabel $\mathrm{Y}$} & 0,1589 \\
\hline
\end{tabular}

Sumber: Data diolah, 2020

Dari tabel di atas dapat kita ketahui bahwa total pengaruh yang diberikan variabel Asosiasi Merek $\left(\mathrm{X}_{2}\right)$ terhadap Kepuasan Konsumen Vitamin Merek Holisticare Ester C Pada Masa Pandemi Covid 19 di Kota Banda Aceh adalah sebesar 15,89\%.

Tabel 6. Pengaruh Langsung dan Tidak Langsung Persepsi Kualitas terhadap Kepuasan Konsumen

\begin{tabular}{lcc}
\hline \multicolumn{2}{c}{ Pengaruh langsung dan tidak langsung } & Besar kontribusi \\
\hline X3 langsung & $\mathrm{P}_{\mathrm{Yx} 3} \mathrm{P}_{\mathrm{Yx} 3}$ & 0,2481 \\
X3 melalui X1 & $\mathrm{P}_{\mathrm{Yx} 3} \mathrm{r}_{\mathrm{x} 1 \times 3} \mathrm{P}_{\mathrm{Yx} 1}$ & 0,0471 \\
$\mathrm{X} 3$ melalui X2 & $\mathrm{P}_{\mathrm{Yx} 3} \mathrm{r}_{\mathrm{x} 2 \times 3} \mathrm{P}_{\mathrm{Yx} 2}$ & 0,0922 \\
\multicolumn{2}{c}{ Total pengaruh Variabel X3 terhadap Variabel Y } & 0,3874 \\
\hline
\end{tabular}
Sumber: Data diolah, 2020

Dari tabel di atas dapat kita ketahui bahwa total pengaruh yang diberikan variabel Persepsi Kualitas $\left(\mathrm{X}_{3}\right)$ terhadap Kepuasan Konsumen Vitamin Merek Holisticare Ester C Pada Masa Pandemi Covid 19 di Kota Banda Aceh adalah sebesar 38,74\%. Untuk lebih jelasnya, besar pengaruh langsung dan tidak langsung dari setiap variabel bebas terhadap variabel Kepuasan Konsumen Vitamin Merek Holisticare Ester C pada Masa Pandemi Covid 19 di 
Kota Banda Aceh yang tertera dalam tabel dibawah ini:

Tabel 7. Pengaruh Total, Langsung, dan Tidak Langsung

\begin{tabular}{lccc}
\hline & \multicolumn{3}{c}{ Kepuasan Konsumen (Y) } \\
\cline { 2 - 4 } & $\begin{array}{l}\text { Pengaruh } \\
\text { langsung }\end{array}$ & $\begin{array}{c}\text { Pengaruh } \\
\text { tidak langsung }\end{array}$ & Pengaruh Total \\
Kesadaran Merek $\left(\mathrm{X}_{1}\right)$ & $1,52 \%$ & $6,83 \%$ & $8,35 \%$ \\
Asosiasi Merek $\left(\mathrm{X}_{2}\right)$ & $4,55 \%$ & $11,33 \%$ & $15,89 \%$ \\
Persepsi Kualitas $\left(\mathrm{X}_{3}\right)$ & $24,81 \%$ & $13,93 \%$ & $38,74 \%$ \\
Pengaruh Total & $30,88 \%$ & $32,10 \%$ & $62,98 \%$ \\
Residu $(\varepsilon)$ & & & $37,02 \%$ \\
\hline
\end{tabular}

Sumber: Data diolah, 2020

Berdasarkan tampilan tabel diatas, maka terlihat bahwa variabel Kesadaran Merek mempunyai pengaruh langsung terhadap Kepuasan Konsumen sebesar 1,53\%, dan pengaruh tidak langsung melalui hubungannya dengan variabel Asosiasi Merek dan Persepsi Kualitas sebesar 6,83\%, sehingga total pengaruhnya terhadap Kepuasan Konsumen adalah sebesar 8,35\%. Variabel Asosiasi Merek mempunyai pengaruh langsung terhadap Kepuasan Konsumen sebesar 4,55\%, dan pengaruh tidak langsung melalui hubungannya dengan variabel Kesadaran Merek dan Persepsi Kualitas sebesar 11,33\%, sehingga total pengaruhnya terhadap Kepuasan Konsumen adalah sebesar 15,89\%. Variabel Persepsi Kualitas mempunyai pengaruh langsung terhadap Kepuasan Konsumen sebesar 24,81\%, dan pengaruh tidak langsung melalui hubungannya dengan variabel Kesadaran Merek dan Asosiasi Merek sebesar $13,93 \%$, sehingga total pengaruhnya terhadap Kepuasan Konsumen adalah sebesar 38,74\%. Dari perhitungan tersebut diperoleh total pengaruh variabel Kesadaran Merek, Asosiasi Merek, dan Persepsi Kualitas terhadap Kepuasan Konsumen adalah sebesar 62,98\%, sedangkan pengaruh faktor lainnya terhadap Kepuasan Konsumen ditunjukkan oleh nilai $\varepsilon=$ 37,02\%. Dengan kata lain, variasi pada variabel Kepuasan Konsumen dapat dijelaskan sebesar 62,98\% oleh variabel Kesadaran Merek, Asosiasi Merek, dan Persepsi Kualitas. Sisanya sebesar 62,98\% variabel Kepuasan Konsumen dapat dijelaskan oleh variabel lain yang tidak diteliti.

Pengujian hipotesis kedua dengan menggunakan analisis jalur dilakukan untuk mengetahui besar pengaruh variabel Kesadaran Merek $\left(\mathrm{X}_{1}\right)$, Asosiasi Merek $\left(\mathrm{X}_{2}\right)$, Persepsi Kualitas $\left(\mathrm{X}_{3}\right)$, dan Kepuasan Konsumen (Y) terhadap Niat Membeli Ulang Vitamin Merek Holisticare Ester C pada Masa Pandemi Covid 19 di Kota Banda Aceh (Z). Dalam metode analisis jalur, untuk mengetahui pengaruh variabel-variabel penelitian atau hubungan kausal 
antar variabel penelitian, maka terlebih dahulu perlu dilakukan perhitungan matriks korelasi dari variabel Kesadaran Merek $\left(\mathrm{X}_{1}\right)$, Asosiasi Persepsi $\left(\mathrm{X}_{2}\right)$, dan Persepsi Kualitas $\left(\mathrm{X}_{3}\right)$ terhadap Niat Membeli Ulang Vitamin Merek Holisticare Ester C pada Masa Pandemi Covid 19 di Kota Banda Aceh (Z).

Hasil dari pengujian korelasi bivariat seluruh variabel yang diuji adalah signifikan (probability di bawah 0,05). Dari hasil perhitungan korelasi tersebut, terdapat bahwa variabel yang memiliki hubungan paling erat dengan variabel Niat Membeli Ulang (Z) adalah variabel Persepsi Kualitas $\left(\mathrm{X}_{3}\right)$, yaitu sebesar 0,740. Sedangkan variabel yang memiliki hubungan paling kecil dengan variabel Niat Membeli Ulang $(\mathrm{Z})$ adalah variabel Asosiasi Merek $\left(\mathrm{X}_{2}\right)$, yaitu sebesar 0,721. Dalam hal ini, nilai korelasi antara Niat Membeli Ulang (Z) dengan variabel Persepsi Kualitas $\left(\mathrm{X}_{3}\right)$ lebih besar dibandingkan dengan variabel bebas lainnya. Hal ini mengindikasikan bahwa Persepsi Kualitas $\left(\mathrm{X}_{3}\right)$ lebih berpengaruh terhadap faktor Niat Membeli Ulang (Z) dibandingkan dengan variabel lainnya (Kesadaran Merek dan Asosiasi Merek). Berikut hasil perhitungan koefisien jalur (Path Analysis) yang digambarkan dalam gambar jalur dibawah ini:

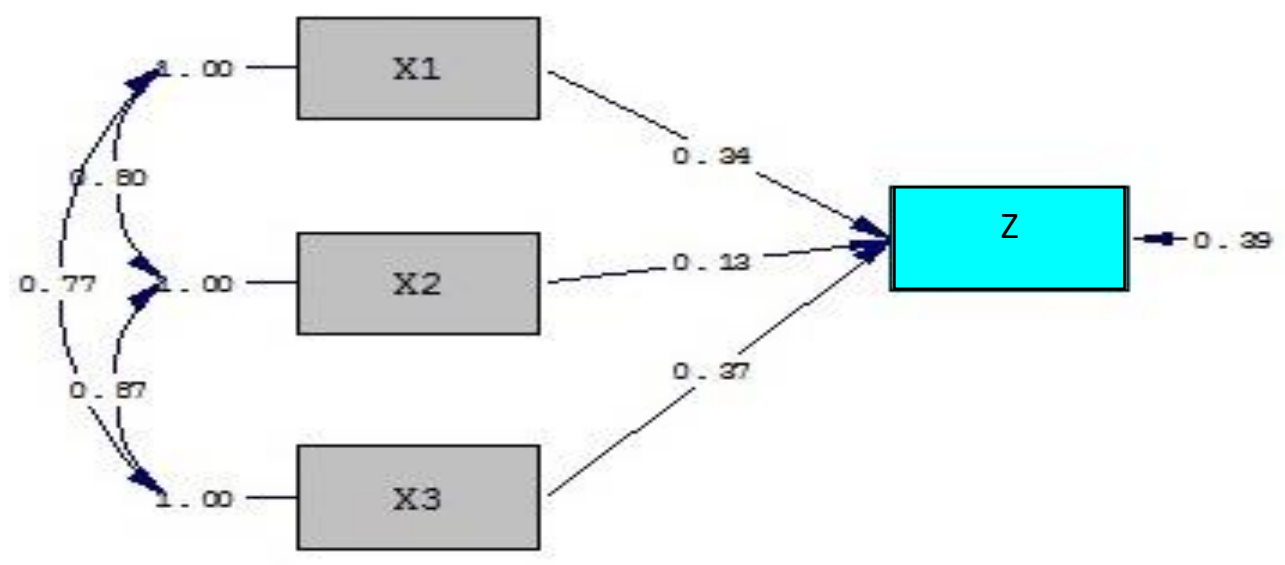

Gambar 5. Hasil Pengujian Jalur 2

Berdasarkan gambar jalur di atas, dapat diformulasikan nilai koefisien jalur pada tabel sebagai berikut:

Tabel 8. Hasil Perhitungan Jalur

\begin{tabular}{lc}
\hline \multicolumn{1}{c}{ Variabel } & Koefisien Jalur \\
\hline Kesadaran Merek $\left(\mathrm{X}_{1}\right)$ & $\rho_{y 2 x 1}=0,338$ \\
Asosiasi Merek $\left(\mathrm{X}_{2}\right)$ & $\rho_{y 2 x 2}=0,133$ \\
Persepsi Kualitas $\left(\mathrm{X}_{3}\right)$ & $\rho_{y 2 x 3}=0,365$ \\
\hline
\end{tabular}

Sumber: Data diolah, 2020 
Berdasarkan hasil perhitungan jalur dari tabel di atas, menggambarkan persamaan jalur sebagai berikut:

Dimana:

$$
Z=0,338 X_{1}+0,133 X_{2}+0,365 X_{3}
$$

$\mathrm{X}_{1}=$ Kesadaran Merek

$\mathrm{X}_{2}=$ Asosiasi Merek

$\mathrm{X}_{3}=$ Persepsi Kualitas

$\mathrm{Z}=$ Niat Membeli Ulang

Dari hasil persamaan di atas dapat diartikan bahwa setiap peningkatan Kesadaran Merek sebesar satu satuan, maka akan meningkatkan Niat Membeli Ulang (karena nilainya positif) sebesar 0,338 satuan. Setiap peningkatan Asosiasi Merek sebesar satu satuan, maka akan meningkatkan Niat Membeli Ulang sebesar 0,133 satuan. Untuk setiap peningkatan Persepsi Kualitas sebesar satu satuan, maka akan meningkatkan Niat Membeli Ulang sebesar 0,365 satuan. Nilai koefisien jalur variabel Persepsi Kualitas lebih besar dibandingkan koefisien jalur untuk variabel bebas lainnya, artinya Persepsi Kualitas lebih menentukan (berpengaruh lebih besar) terhadap Niat Membeli Ulang dibandingkan variabel bebas lainnya, baik secara langsung maupun tak langsung.

Untuk menguji signifikansi pada hipotesis kedua dalam penelitian ini, dilakukan pengujian hipotesis secara simultan. Hipotesis kedua penelitian ini adalah Kesadaran Merek $\left(\mathrm{X}_{1}\right)$, Asosiasi Persepsi $\left(\mathrm{X}_{2}\right)$, Persepsi Kualitas $\left(\mathrm{X}_{3}\right)$, dan Kepuasan Konsumen $(\mathrm{Y})$ terhadap Niat Membeli Ulang Vitamin Merek Holisticare Ester C pada Masa Pandemi Covid 19 di Kota Banda Aceh (Z). Berikut hasil pengujian simultan untuk hipotesis kedua :

Tabel 9. Pengujian Secara Simultan

\begin{tabular}{|c|c|c|c|c|}
\hline Hipotesis Alternatif & F hitung & $\overline{d b}$ & F table & Kesimpulan \\
\hline $\begin{array}{c}\left(X_{1}, X_{2}, X_{3}\right) \text { secara simultan } \\
\text { berpengaruh terhadap } Z\end{array}$ & 128,705 & $\begin{array}{l}\mathrm{db}_{1}=3 \\
\mathrm{db}_{2}=246\end{array}$ & 2,764 & $\begin{array}{c}\text { Ho ditolak } \\
\text { (Signifikan) }\end{array}$ \\
\hline
\end{tabular}

Sumber: Data diolah, 2020

Pada tabel di atas dapat kita ketahui bahwa hasil pengujian signifikan yang berarti Kesadaran Merek $\left(\mathrm{X}_{1}\right)$, Asosiasi Persepsi $\left(\mathrm{X}_{2}\right)$, Persepsi Kualitas $\left(\mathrm{X}_{3}\right)$ simultan berpengaruh terhadap Niat Membeli Ulang Vitamin Merek Holisticare Ester C pada Masa Pandemi Covid 19 di Kota Banda Aceh (Z). Dikarenakan hasil pengujian yang telah dilakukan secara simultan memberikan hasil yang signifikan, maka diperlukan pengujian untuk mengetahui variabel bebas mana yang secara parsial berpengaruh nyata dan signifikan terhadap Niat Membeli Ulang Vitamin Merek Holisticare Ester C pada Masa Pandemi Covid 19 di Kota 
Banda Aceh (Z) yang ditampilkan dalam tabel berikut ini:

Tabel 10. Pengujian Secara Parsial

\begin{tabular}{ccccccc}
\hline No & Hipotesis & Koefisien Jalur & t hitung & db & t table & Kesimpulan \\
\hline $\mathbf{1}$ & $\mathrm{P}_{\mathrm{Zx} 1} \neq 0$ & 0,338 & 4,907 & 248 & 1.97 & Ho ditolak \\
$\mathbf{2}$ & $\mathrm{P}_{\mathrm{Zx} 2} \neq 0$ & 0,133 & 1,497 & & 1.97 & Ho diterima \\
$\mathbf{3}$ & $\mathrm{P}_{\mathrm{Zx} 3} \neq 0$ & 0,365 & 4,442 & & 1.97 & Ho ditolak \\
\hline
\end{tabular}

Sumber: Data diolah, 2020

Tabel di atas menunjukkan bahwa semua nilai t hitung untuk ketiga variabel bebas lebih besar dari nilai t tabel, hal ini berarti variabel Kesadaran Merek $\left(\mathrm{X}_{1}\right)$, dan Persepsi Kualitas $\left(\mathrm{X}_{3}\right)$ secara parsial memberikan pengaruh yang signifikan terhadap Niat Membeli Ulang Makanan. Sedangkan variabel Asosiasi Persepsi $\left(\mathrm{X}_{2}\right)$ tidak mempunyai pengaruh signifkan terhadap Niat Membeli Ulang Vitamin Merek Holisticare Ester C pada Masa Pandemi Covid 19 di Kota Banda Aceh. Selanjutnya dihitung pengaruh langsung dan tidak langsung untuk hipotesis pertama yang ditampilkan dalam tabel sebagai berikut :

Tabel 11. Pengaruh Langsung dan Tidak Langsung Kesadaran Merek terhadap Niat Membeli Ulang

\begin{tabular}{ccc}
\hline \multicolumn{2}{c}{ Pengaruh langsung dan tidak langsung } & Besar kontribusi \\
\hline X1 langsung & $\mathrm{P}_{\mathrm{Zx} 1} \mathrm{P}_{\mathrm{Zx} 1}$ & 0,1141 \\
$\mathrm{X} 1$ melalui X2 & $\mathrm{P}_{\mathrm{Zx} 1} \mathrm{r}_{\mathrm{x} 1 \times 2} \mathrm{P}_{\mathrm{Zx} 2}$ & 0,0360 \\
$\mathrm{X} 1$ melalui X3 & $\mathrm{P}_{\mathrm{Zx} 1} \mathrm{r}_{\mathrm{x} 1 \times 3} \mathrm{P}_{\mathrm{Zx} 3}$ & 0,0947 \\
\multicolumn{2}{c}{ Total pengaruh X1 terhadap Z } & 0,2449 \\
\hline
\end{tabular}

Sumber: Data diolah, 2020

Tabel di atas dapat kita ketahui bahwa total pengaruh yang diberikan variabel Kesadaran Merek $\left(\mathrm{X}_{1}\right)$ terhadap Niat Membeli Ulang Vitamin Merek Holisticare Ester C Pada Masa Pandemi Covid 19 di Kota Banda Aceh adalah sebesar 24,49\%.

Tabel 12. Pengaruh Langsung dan Tidak Langsung Asosiasi Persepsi terhadap Niat Membeli Ulang

\begin{tabular}{lcc}
\hline \multicolumn{2}{c}{ Pengaruh langsung dan tidak langsung } & Besar kontribusi \\
\hline X2 langsung & $\mathrm{P}_{\mathrm{Zx} 2} \mathrm{P}_{\mathrm{Zx} 2}$ & 0,0176 \\
$\mathrm{X} 2$ melalui X1 & $\mathrm{P}_{\mathrm{Zx2}} \mathrm{r}_{\mathrm{x} 1 \times 2} \mathrm{P}_{\mathrm{Zx} 1}$ & 0,0360 \\
$\mathrm{X} 2$ melalui X3 & $\mathrm{P}_{\mathrm{Zx2} 2} \mathrm{r}_{\mathrm{x} 2 \times 3} \mathrm{P}_{\mathrm{Zx} 3}$ & 0,0421 \\
Total pengaruh X2 terhadap Z & & 0,0957 \\
\hline
\end{tabular}

Sumber : Data diolah, 2020

Tabel di atas dapat kita ketahui bahwa total pengaruh yang diberikan variabel Asosiasi Persepsi $\left(\mathrm{X}_{2}\right)$ terhadap variabel Niat Membeli Ulang Vitamin Merek Holisticare Ester C Pada Masa Pandemi Covid 19 di Kota Banda Aceh adalah sebesar 9,57\%. 
Tabel 13. Pengaruh Langsung dan Tidak Langsung Persepsi Kualitas terhadap Niat Membeli Ulang

\begin{tabular}{lcc}
\hline \multicolumn{2}{c}{ Pengaruh langsung dan tidak langsung } & Besar kontribusi \\
\hline X3 langsung & $\mathrm{P}_{\mathrm{Zx3}} \mathrm{P}_{\mathrm{Zx3}}$ & 0,1335 \\
X3 melalui X1 & $\mathrm{P}_{\mathrm{Zx3}} \mathrm{r}_{\mathrm{x} 1 \times 3} \mathrm{P}_{\mathrm{Zx} 1}$ & 0,0947 \\
X3 melalui X2 & $\mathrm{P}_{\mathrm{Zx3}} \mathrm{r}_{\mathrm{x} 2 \times 3} \mathrm{P}_{\mathrm{Zx2}}$ & 0,0421 \\
Total pengaruh X3 terhadap Z & & 0,2703 \\
\hline
\end{tabular}

Sumber : Data diolah, 2020

Tabel di atas dapat kita ketahui bahwa total pengaruh yang diberikan variabel Persepsi Kualitas $\left(\mathrm{X}_{3}\right)$ terhadap variabel faktor Niat Membeli Ulang Vitamin Merek Holisticare Ester C Pada Masa Pandemi Covid 19 di Kota Banda Acehsebesar 27,03\%.

Maka untuk lebih jelasnya besar pengaruh langsung dan tidak langsung dari setiap variabel bebas terhadap variabel Niat Membeli Ulang Vitamin Merek Holisticare Ester C pada Masa Pandemi Covid 19 di Kota Banda Aceh disajikan dalam tebel berikut :

Tabel 14. Pengaruh Total dan Pengaruh Langsung

\begin{tabular}{lccc}
\hline & \multicolumn{3}{c}{ Niat Membeli Ulang $(\mathbf{Z})$} \\
\cline { 2 - 4 } & $\begin{array}{c}\text { Pengaruh } \\
\text { langsung }\end{array}$ & $\begin{array}{c}\text { Pengaruh } \\
\text { tidak } \\
\text { langsung }\end{array}$ & Pengaruh Total \\
Kesadaran Merek $\left(\mathrm{X}_{1}\right)$ & $11,41 \%$ & $13,08 \%$ & $24,49 \%$ \\
Asosiasi Merek $\left(\mathrm{X}_{2}\right)$ & $1,76 \%$ & $7,81 \%$ & $9,57 \%$ \\
Persepsi Kualitas $\left(\mathrm{X}_{3}\right)$ & $13,35 \%$ & $13,68 \%$ & $27,03 \%$ \\
Pengaruh Total & $26,52 \%$ & $34,56 \%$ & $61,08 \%$ \\
Residu $(\varepsilon)$ & & & $38,92 \%$ \\
\hline
\end{tabular}

Sumber : Data diolah, 2020

Berdasarkan tabel pengaruh total dan pengaruh langsunng diatas, terlihat bahwa variabel Kesadaran Merek mempunyai pengaruh langsung terhadap Niat Membeli Ulang sebesar $11,41 \%$, dan pengaruh tidak langsung melalui hubungannya dengan variabel Asosiasi Merek dan Persepsi Kualitas sebesar 13,08\%, sehingga total pengaruhnya terhadap faktor Niat Membeli Ulang adalah sebesar 24,49\%. Variabel Asosiasi Merek mempunyai pengaruh langsung terhadap Niat Membeli Ulang sebesar 1,76\%, dan pengaruh tidak langsung melalui hubungannya dengan variabel Kesadaran Merek dan Persepsi Kualitas sebesar 7,81\%, sehingga total pengaruhnya terhadap Niat Membeli Ulang adalah sebesar 9,57\%. Variabel Persepsi Kualitas mempunyai pengaruh langsung terhadap Niat Membeli Ulang sebesar 13,35\%, dan pengaruh tidak langsung melalui hubungannya dengan variabel Kesadaran Merek dan Asosiasi Merek sebesar 13,68\%, sehingga total pengaruhnya terhadap Niat Membeli Ulang adalah sebesar 27,03\%. Dari perhitungan tersebut diperoleh total pengaruh 
variabel Kesadaran Merek, Asosiasi Merek, dan Persepsi Kualitas terhadap Niat Membeli Ulang adalah sebesar $61,08 \%$, sedangkan pengaruh faktor lainnya terhadap Niat Membeli Ulang ditunjukkan oleh nilai $\varepsilon=38,92 \%$. Dengan kata lain, variasi pada variabel Niat Membeli Ulang dapat dijelaskan sebesar 61,08\% oleh variabel Kesadaran Merek, Asosiasi Merek, dan Persepsi Kualitas. Sisanya sebesar 38,92\% variabel Niat Membeli Ulang dapat dijelaskan oleh variabel lain yang tidak diteliti.

Pengujian yang terakhir adalah pengujian hipotesis ketiga yaitu untuk mengetahui besar pengaruh variabel Kepuasan Konsumen (Y) terhadap Niat Membeli Ulang Vitamin Merek Holisticare Ester C pada Masa Pandemi Covid 19 di Kota Banda Aceh (Z). Dalam analisis jalur yang terakhir ini, terlebih dahulu dilakukan perhitungan matriks korelasi dari variabel Kepuasan Konsumen (Y) terhadap Niat Membeli Ulang Vitamin Merek Holisticare Ester C pada Masa Pandemi Covid 19 di Kota Banda Aceh (Z)

Hasil dari korelasi bivariat yang ditunjukkan pada tabel diatas, menampilkan indikasi awal adanya hubungan antar variabel. Dari tabel diatas terlihat bahwa korelasi bivariat variabel adalah signifikan (probability di bawah 0,05). Hasil perhitungan koefisien jalur (Path Analysis) adalah sebagai berikut:

1.00

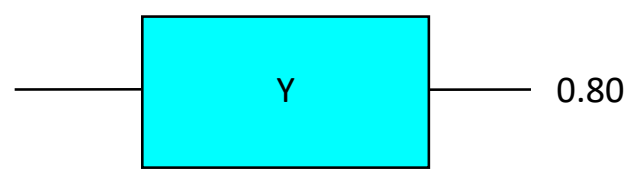

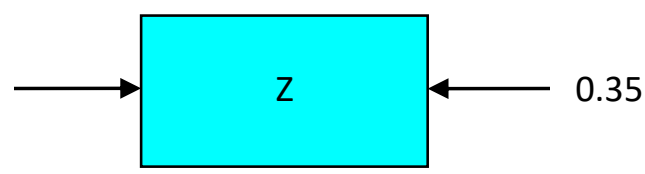

Gambar 6. Hasil Pengujian Jalur 3

Berdasarkan gambar analisis jalur di atas, maka dapat diformulasikan nilai koefisien jalur yang ditampilkan dalam tabel dibawah ini :

Tabel 15. Hasil Perhitungan Jalur

\begin{tabular}{lc}
\hline \multicolumn{1}{c}{ Variabel } & \multicolumn{1}{c}{ Koefisien Jalur } \\
\hline Kepuasan Konsumen $(\mathrm{Y})$ & $\mathrm{Pzy}=0,804$ \\
\hline Sumber : Data diolah, 2020
\end{tabular}

Berdasarkan tabel diatas, diperoleh persamaan jalur sebagai berikut:

$\mathrm{Z}=0,804 \mathrm{Y}$

Dimana:

$\mathrm{Y}=$ Kepuasan Konsumen

$\mathrm{Z}=$ Niat Membeli Ulang

Dari persamaan jalur di atas dapat diartikan bahwa setiap peningkatan kepuasan konsumen sebesar satu satuan, maka akan meningkatkan Niat Membeli Ulang sebesar 0,804 
satuan.

Untuk menguji signifikansi pada hipotesis ketiga, dilakukan pengujian hipotesis secara simultan. Pada hipotesis ketiga ini tidak ada pengujian secara parsial. Hipotesis ketiga pada penelitian ini adalah Kepuasan Konsumen (Y) mempunyai pengaruh terhadap Niat Membeli Ulang Vitamin Merek Holisticare Ester C pada Masa Pandemi Covid 19 di Kota Banda Aceh (Z). Hasil pengujian secara simultan pada hipotesis ketiga tertera dalam tabel dibawah ini:

Tabel 16. Pengujian Secara Simultan

\begin{tabular}{ccccc}
\hline Hipotesis Alternatif & F hitung & Db & F tabel & Kesimpulan \\
\hline Y secara simultan & 452,614 & $\mathrm{db}_{1}=3$ & 2,764 & $\begin{array}{c}\text { Ho ditolak } \\
\text { (Signifikan) }\end{array}$ \\
berpengaruh terhadap $\mathrm{Z}$ & & $\mathrm{db}_{2}=246$ & & \\
\hline
\end{tabular}

Sumber : Data diolah, 2020

Pada tabel di atas dapat disimpulkan bahwa hasil pengujian signifikan yang berarti Kepuasan Konsumen (Y) simultan berpengaruh terhadap Niat Membeli Ulang Vitamin Merek Holisticare Ester C pada Masa Pandemi Covid 19 di Kota Banda Aceh (Z).

Tabel 17. Pengaruh Langsung dan Kepuasan Konsumen terhadap Niat Membeli Ulang

\begin{tabular}{ccc}
\hline \multicolumn{2}{c}{ Pengaruh langsung dan tidak langsung } & Besar kontribusi \\
\hline Y langsung & $\mathrm{P}_{Z Y} \mathrm{P}_{\mathrm{ZY}}$ & 0,6460 \\
\hline
\end{tabular}

Sumber : Data diolah, 2020

Dari tabel di atas dapat kita ketahui bahwa total pengaruh yang diberikan variabel Kepuasan Konsumen (Y) terhadap Niat Membeli Ulang Vitamin Merek Holisticare Ester C pada Masa Pandemi Covid 19 di Kota Banda Aceh adalah sebesar 64,60\%.

\section{Perubahan Model Penelitian}

Berdasarkan hasil penelitian dan pembahasan dalam pengujian hipotesis dapat disimpulkan terdapat perbedaan model penelitian awal ditampilkan pada Gambar 7 dengan model akhir dari penelitian ini yang ditunjukkan dalam Gambar 8. Perbedaan diantara model yang dikemukakan adalah pada Pengujian hipotesis secara parsial menunjukkan bahwa variabel kesadaran merek tidak mempunyai pengaruh yang siginifikan terhadap kepuasan konsumen Vitamin Merek Holisticare Ester C pada Masa Pandemi Covid 19 di Kota Banda Aceh, dan Pengujian hipotesis kedua secara parsial menunjukkan bahwa variabel asosiasi merek tidak mempunyai pengaruh yang signifikan terhadap niat membeli ulang Vitamin Merek Holisticare Ester C pada Masa Pandemi Covid 19 di Kota Banda Aceh. Model akhir dapat dilihat pada Gambar 8. Hasil penelitian tersebut dapat ditunjukkan dalam gambar sebagai berikut : 


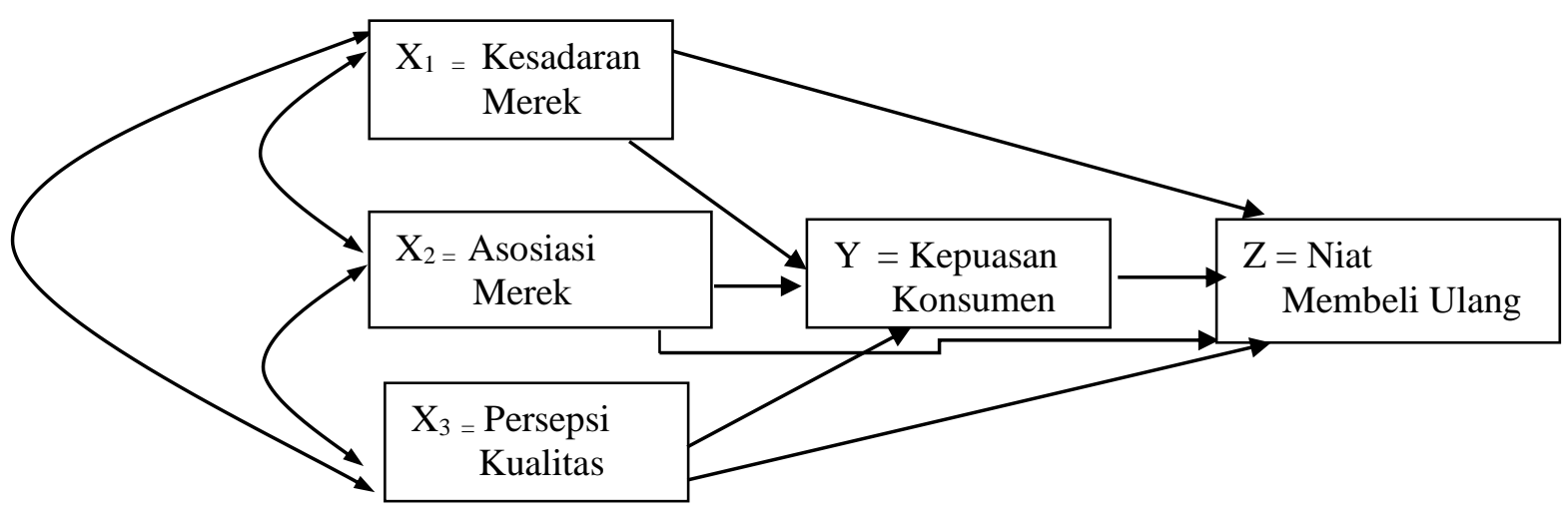

Gambar 7. Model Awal Penelitian

Karena adanya pengaruh yang tidak signifikan antara variabel kesadaran merek terhadap kepuasan konsumen dan variabel asosiasi merek terhadap niat membeli ulang Vitamin Merek Holisticare Ester C pada Masa Pandemi Covid 19 di Kota Banda Aceh, maka model akhir dari penelitian ini menjadi seperti berikut :

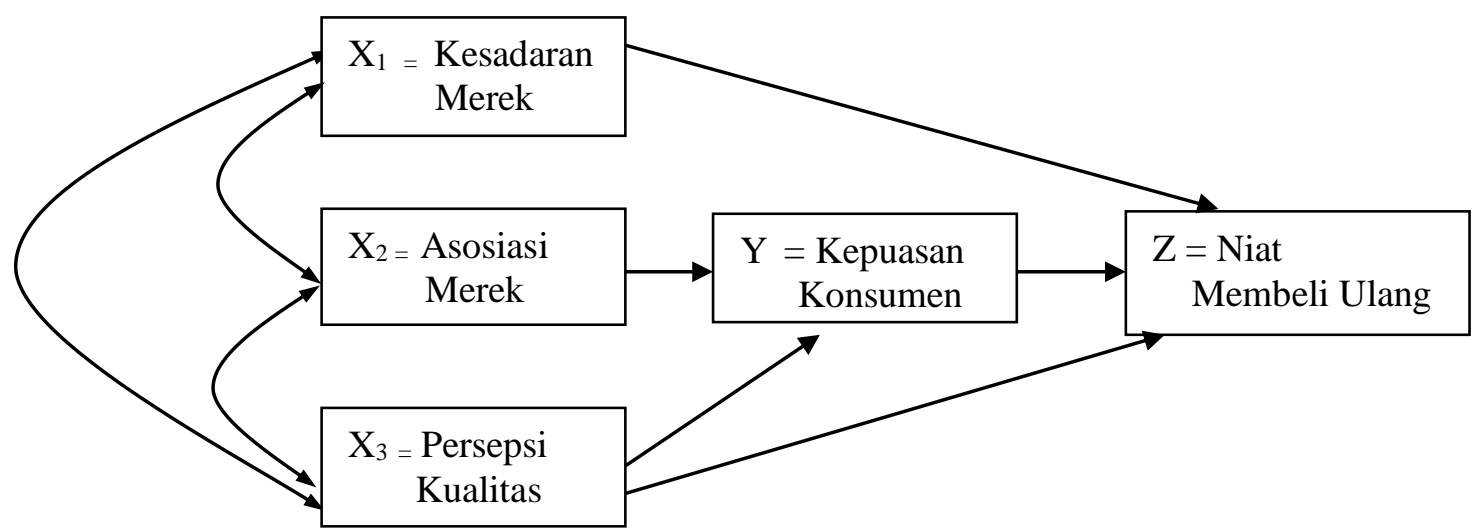

Gambar 8. Model Akhir Penelitian

\section{KESIMPULAN}

Hasil penelitian untuk hipotesis pertama diperoleh penjelasan bahwa ketiga variabel Kesadaran Merek, Asosiasi Merek, dan Persepsi Kualitas secara simultan atau bersama-sama mempunyai pengaruh yang signifikan terhadap Kepuasan Konsumen Vitamin Merek Holisticare Ester C pada masa pandemi Covid 19 di Kota Banda Aceh. Hasil penelitian terhadap hipotesis kedua diperoleh penjelasan bahwa ketiga variabel penelitian yaitu Kesadaran Merek, Asosiasi Merek, dan Persepsi Kualitas secara bersama-sama memiliki pengaruh yang signifikan terhadap Niat Membeli Ulang Vitamin Merek Holisticare Ester C pada masa pandemi di Kota Banda Aceh. Sedangkan hasil yang diperoleh pada pengujian 
hipotesis ketiga dapat dijelaskan bahwa variabel Kepuasan Konsumen memiliki pengaruh yang signifikan terhadap Niat Membeli Ulang Vitamin Merek Holisticare Ester C pada masa pandemi Covid 19 di Kota Banda Aceh.

Dari hasil penelitian yang sudah dilakukan, variabel kesadaran merek dan asosiasi merek mempunyai nilai pengaruh lebih rendah dibandingkan dengan variabel persepsi kualitas, hal ini mengindikasikan bahwa pihak perusahaan harus lebih memperhatikan, menyadarkan konsumen dan menempatkan produknya dibenak konsumen dengan lebih baik lagi sehingga akan tercipta kepuasan konsumen yang pada akhirnya akan timbul niat untuk membeli ulang produk. Ketiga variabel yaitu kesadaran merek, asosiasi merek dan persepsi kualitas yang tergolong dalam ekuitas merek hendaknya mendapat perhatian dari pihak perusahaan, karena untuk dapat terciptanya kepuasan konsumen sehingga timbulnya niat membeli ulang diperlukan suatu ekuitas merek yang kuat, dengan begitu tujuan perusahaan akan dengan mudah dicapai, serta pihak perusahaan juga hendaknya selalu mengadakan promosi secara kontinyu dan intensif untuk memperkuat "brand image". Kemudian agar terciptanya kepuasan konsumen, hendaknya kesadaran merek, asosiasi merek dan persepsi kualitas tidak hanya sebatas pemahaman saja, tetapi harus benar-benar menjadi perhatian dan perlu ditingkatkan lagi, supaya kepuasan konsumen itu berada pada level yang paling maksimal sehingga timbul niat untuk membeli ulang yang berujung pada terciptanya sebuah loyalitas konsumen.

\section{REFERENSI}

Armstrong, Gary and Kotler, Philip. (2011). Marketing an Introduction Global Edition. New Jersey : Prentice Hall.

Hakam,Malik, Sudarno dan Hoyyi Abdul. (2015). Analisis Jalur Terhadap Faktor-Faktor Yang Mempengaruhi Indeks Prestasi Kumulatif (IPK) Mahasiswa Statistik UNDIP. Jurnal Gaussian 61-70. https://ejournal3.undip.ac.id/index.php/gaussian/article/view/8146

Irzandy, Mas Aga Haris, Suharyono, Arifin Zainul. (2017). Pengaruh Ekuitas Merek terhadap Minat Beli dan Dampaknya pada Keputusan Pembelian. (Survei Pada Pengguna Kartu Perdana Simpati Khusus Internet Di Grapari Telkomsel Cabang Kota Malang). Jurnal $\begin{array}{llll}\text { Administrasi dan Bisnis } & \text { (JAB) } & \text { 51(1), } & 151-158\end{array}$ http://administrasibisnis.studentjournal.ub.ac.id/

Kartajaya, Hermawan. (2000). Marketing Plus 2000: Siasat Memenangkan Persaingan Global. Jakarta: Gramedia Utama.

Kerin, Roger. A, et all. (2011). Marketing in Asia. New Jersey: Mc.Graw Hill Companies,Inc. Malhotra, Naresh K. (2005). Marketing Reseach: an Applied Orientation. Fourth Edition. New Delhi: Prentice-Hall of India.

Maulida, Zenitha dan Nurbismi. (2017). Pengaruh Kualitas dan Harga Air Minuman dalam Kemasan Merek Ades terhadap Kepuasan Konsumen di Kota Banda Aceh. Jurnal Si$\begin{array}{lllll}\text { Men } \quad \text { (Akuntansi dan } & \text { Manajemen) } & \text { STIES }\end{array}$ 
http://jurnal.stiesabang.ac.id/index.php/simen/article/view/79

Ma'ruf, Jasman. J. (2005). Riset Perilaku Konsumen: Niat Membeli Melalui Internet. Banda Aceh: Program Magister Manajemen Universitas Syiah Kuala.

Sarwono, Jonathan. (2007). Analisis Jalur untuk Riset Bisnis dengan SPSS. Yogyakarta: Andi. Schiffman, Leon G and Kanuk, Leslie Lazar. (2011). Consumer Behavior. Tenth edition. New Jersey: Prentice Hall. 